\title{
Establishment of resistance to Leishmania major infection in susceptible BALB/c mice requires parasite-specific $\mathrm{CD}^{+}{ }^{+} \mathrm{T}$ cells
}

\author{
Ingrid Müller, Thlerry Pedrazzini, Pascale Kropf, Jacques Louls, and \\ Geneviève Milon' \\ World Health Organıation Immunology Research and Training Centre, Institute of Biochemistry, University \\ of Lausanne, 1066 Epalinges, Switzerland \\ ${ }^{1}$ Unité d'Immunophysiologie Cellulaire, Institut Pasteur, 75724 Paris Cedex 15, France
}

Key words: T cells, Leishmania major parasites

\begin{abstract}
Although $\mathrm{CD4}^{+} \mathrm{T}$ cells are generally accepted to be responslble for the determination of resistance to infection in experimental murine cutaneous lelshmanlasis, a contribution of CD8* lymphocytes to immunity can be demonstrated under certain well-defined conditions. Normally hlghly susceptible BALB/C mice can be rendered resistant to Infection with Lelshmania major promastigotes by a single Injection of monoclonal anti-CD4 antibodies at the beginning of Infection. Mice treated in such a way can heal their primary cutaneolis lesions and acquire Immunity to subsequent challenge Infection. Both the resolution of the primary infection and the Induced state of Immunity to reinfection In these mice ls shown to be dependent upon the antilelshmanlal effector functions of CDB $+\mathrm{T}$ cells. Furthermore, In contrast to control infected BALB/c mice, which are unable to mount a delayed-type hypersensitivity (DTH) response to viable parasites, mice cured as a result of treatment with antl-CD4 antlbodies In vivo exhlbit a strong DTH response, which can be significantly reduced by Injection of either antl-CD4 or antlCD8 monoclonal antlbodies prior to antigenlc challenge with vlable promastigotes. Moreover, Increased numbers of specific CDB ${ }^{+} \mathrm{T}$ cells, able to transfer Lelshmanla-8pecific DTH responses, were found In lymphold organs of BALB/C mice rendered reslstant to infection by Immunolntervention with anti-CD4 monoclonal antibodies at the beginning of infection.

Neutralization In vivo of interleukin 4 during the course of infection In BALB/c mice also enables these othenwise susceptible mice to resolve their cutaneous lesions and to decrease the parasite burden in Infected tissues. CD8 $+\mathrm{T}$ cells are required for both of these beneficial effects. Taken together, these results Indicate that in the immune BALB/C mouse, as in the normally resistant CBA mouse, CD8+ Iymphocytes are Involved In the ellmination of $L$. major and in the establishment and maintenance of immunity against infection with this parasite.
\end{abstract}

\section{Introduction}

Leishmania major, one of the causative agents of cutaneous leishmaniasis in man, is a protozoan parasite that infects mononuclear phagocytes in its vertebrate hosts. The various clinical manifestations of human leishmaniasis can be mimicked in mice from various inbred strains upon infection with $L$. major. The majority of inbred strains of mice are relatively resistant to infection with this parasite in that they develop only small lesions at the site of inoculation, which spontaneously resolve within a few weeks. In contrast, mice from a few strains, such as BALB/c, develop severe lesions at the site of parasite inoculation. These lesions show no tendency to resolve, and eventually fatal visceralization of the infection occurs $(1,2)$.

The importance of $\mathrm{CD} 4{ }^{+} \mathrm{T}$ cells in resolution of cutaneous lesions induced by L. major in mice is firmly established $(3-5)$. However, results are accumulating which indicate that $\mathrm{CD8^{+ }} \mathrm{T}$ cells also participate in the resolution of $L$. major-induced lesions. A role for $\mathrm{CD8}+\mathrm{T}$ cells in immunity to infection with this parasite was first suggested by observations showing the activation of larger numbers of parasite-specific $\mathrm{CD}^{+} \mathrm{T}$ cells in resistant than in susceptible mice during the course of a primary infec-

Correspondence to: J. A. Louis, W.H.O. - Immunology Research and Training Centre, Institute of Biochemistry, University of Lausanne, Chemin des Boveresses 155, $\mathrm{CH}-1066$ Epalinges, Switzertand

Transmitting editor: S. H. E. Kaufmann 
tion (6). Secondly, administration of anti-CD8 monoclonal antibodies was shown to enhance significantly the development of lesions in resistant mice, even though this treatment did not modify the outcome of infection (7). Thirdly, it has recently been shown that adult thymectomized BALB/c mice treated with $\alpha-C D 4$ $\mathrm{mAb}$, which are thus virtually free of $\mathrm{CD} 4+\mathrm{T}$ cells, are able to control infection induced by $L$. major amastigotes through the activity of $\mathrm{CD}^{+} \mathrm{T}$ cells mediating specific delayed-type hypersensitivity (DTH) reactions (8). Fourthly, resistance to infection, acquired by intravenous immunization of susceptible mice with killed promastigotes, was prevented by depletion of CD8 ${ }^{+}$ $T$ cells in vivo (9). Finally, recent results from our laboratory have shown that in resistant mice $\mathrm{CDB}^{+} \mathrm{T}$ cells also appear to be important in controlling the lesions developing upon infectious challenge of immune mice, which had spontaneously cured their primary infections (10).

In the murine model of generalized visceral infection with Leishmania donovani, results show that the majority of specific $T$ cells in the liver of resistant B10 mice, at the time when parasite load begins to decrease rapidly, express the CD8+ surface phenotype (11). Furthermore, $\mathrm{CD}^{+} \mathrm{T}$ cells have been demonstrated to contribute to immunity to reinfection of mice with L. donovani (12).

Several studies have demonstrated that susceptibllity of normal $B A L B / C$ mice to infection with $L$. major can be overcome by varıous immunologıcal interventions. For example, administration of $\alpha$-CD 4 mAb to normal BALB/c mice at the beginning of infection enables them to resolve their primary infection and render them resistant to reinfection $(13-16)$. Treatment of BALB/c mice with $\alpha$-interleukin 4 (IL-4) mAb has also been shown to reverse their extreme susceptibility to infection (17). In the present study, we show that the state of resistance to infection seen in BALB/C mice as a result of either of these two interventions on the immune system depends upon the triggering and the activity of $\mathrm{CD} 8+\mathrm{T}$ cells.

\section{Methods}

Mice

Adult BALB/C mice were either obtained from the animal colony maintained at the Institut Pasteur Paris or purchased from IFFA. Credo, Saint-Germain-sur-l'Arbresle, France.

\section{Parasites}

L. major LV39 (MRHO/SU/59/P-strain) was kept virulent by continuous passage into mice. Parasites isolated from skin lesions of infected mice were grown at $26^{\circ} \mathrm{C}$ in Dulbecco's modified Eagle's medium (DMEM) on a solid layer of rabbit blood-agar as previously described (18).

\section{Infection of mice and monitoring of lesions}

Mice were infected s.c. in one hind footpad with $2 \times 10^{6} \mathrm{~L}$. major promastigotes, obtained from cultures in the stationary growth phase, in a final volume of $50 \mu$. The development of lesions was monitored weekly by measuring the increase of footpad thickness compared to the uninfected contralateral footpad. Determination of the number of viable L. major parasites in
infected mouse tissues

Viable $L$. major parasites in infected tissues were enumerated using a limiting dilution assay described elsewhere (19). Briefly, dilutions of infected tissue homogenates were placed in the wells of microtiter plates which contained rabbit blood-agar stants. After $10-12$ days incubation at $26^{\circ} \mathrm{C}$, the wells contanning growing parasites were identified by microscopic examination. Estimation of the frequency of $L$. major recovered from a given tissue was determined by minimum $\chi^{2}$ analysis applied to Poisson distribution.

\section{Delayed-type hypersensitivity (DTH)}

DTH responses were elıcited by s.c. injection of either $2 \times 10^{6}$ infective $L$. major promastigotes or frozen-and-thawed lysates of L. major promastigotes (L.m.Ag) in a final volume of $50 \mu$ into one hind footpad. The doses of L.m.Ag employed are expressed in terms of the numbers of promastigotes used to prepare the antigen. The DTH reaction was quantitated by measuring at various times $(6,12,24$, and $48 \mathrm{~h})$ the increase in footpad thickness, ı.e. the difference between the thickness of the injected footpad and the control footpad by using a dial-gauge caliper (precision $0.05 \mathrm{~mm}$. Krōplın, Schlüchtern, FRG).

Estimation of the frequency of L. major specific $T$ cells capable of mediating specific DTH reaction

The adoptive transfer of DTH reactıon was performed by ınjecting cells from sensitized animals together with viable $L$. major promastıgotes as antıgen into one hind footpad of normal syngeneic mice. The limiting dilution analysis to determine the frequency of DTH-mediating T cells in lymphoid tissues has been described $(20,21)$. In brief, three serial dilutions of lymphod cells were mixed with viable $L$. major promastigotes, and $50 \mu$ l of cell suspensions were injected into one hind footpad of normal syngeneic mice (10-12 recipients for each dilution). The DTH reaction was quantitated by measuring the increase in footpad thickness $18 \mathrm{~h}$ later. Since the DTH-mediating activity is reflected by an increase in footpad thickness, the frequency determinatıon of DTH-mediating T cells by limiting dilution assay implies the definition of values in which the swelling footpad response is scored as negative (negative transfer). The upper value of footpad thickness increase related to negative transfer was calculated from the mean $(\mathrm{m})$ value of increase of footpad thickness measured after local injection of diluted suspensions of unsensitized cells (or sensitized cells against an unrelated antigen) mixed with $2 \times 10^{6} \mathrm{~L}$. major promastigotes, into $10-12$ naive recipients. To this value $(m)$ was added the product $\mathrm{SD} \times t_{005}$ in which SD represents the standard deviation and $t$ is the value of Student's $t$ for $P=0.05$. The experımental values were always inferior to such a calculated value $(0.20 \mathrm{~mm})$ when cell suspensions and antigen were prepared under the appropriate conditions and mice were kept on a clean litter. The frequency of specific $T$ cells was calculated as described (6).

\section{mAbs}

Rat mAb GK 1.5 (lgG2b, $\alpha$-CD4) (22) and $\alpha$-CD8 mAb $31 \mathrm{M}$ (IgM) (23) were kindly provided by Dr F. W. Fitch, University of Chicago, Chicago, IL. Rat mAb H35.17.2 (IgG2b, $\alpha$-CD8) (24) was kindly supplied by Dr M. Pierres, INSERM/CNRS, Marseille, France. Rat mAb 11B11 (IgG1, $\alpha$-murine-IL-4) (25) was a gift of Dr W. Paul, National Institutes of Health, Bethesda, Maryland, USA and rat mAb AN-18.17.24 ( $\alpha$-murine interferon (IFN- $\gamma$ ) was a gift of Dr S. Landolfo, University of Torino, Torino, Italy (26). Rat mAb R4-6A2 (IgG1, $\alpha$-murine IFN- $\gamma$ ) (27) was obtained by Dr G. Spitalny. Rat mAb RL $172.4(\operatorname{lgM}, \alpha$-CD4) (28) was a gift of $\mathrm{Dr}$ 
H. R. MacDonald, Ludwig Institute for Cancer Research, Epalinges, Switzerland. $\alpha$-DNP mAb LO-DNP-11 (rat, IgG 2b) was kindly provided by Dr H. Bazin. Brussels, Belgium (29).

\section{Treatment with $M A b$ in vivo}

Unless otherwise stated, semi-purified mAb (ammonium sulphate precipitation) from ascites fluid were injected i.p. or i.v. in phosphate-buffered salıne at the indicated doses.

Preparation of $T$ cell subset-depleted cell suspensions from lymphoid tıssues

Before transfer, single-cell suspensions $\left(5 \times 10^{7}\right.$ nucleated cells $/ \mathrm{ml}$ ) were incubated with a $1 / 10$ dilution of hybridoma culture supernatant containing $\mathrm{mAb}(\mathrm{IgM})$ directed against either the CD4 or CD8 T cell surface antigen and a $1 / 40$ dilution of guinea pig serum as a source of complement. The $T$ cell subset-depleted suspensions were washed twice before use in adoptive transfer experiments

Two-color fluorescence staining and fluorescence-activated cell sorter (FACS) analysis

Samples of $2 \times 10^{6}$ cells were stanned with a mixture of phycoerythrin-labeled $\alpha$-CD4 mAb (GK 1.5, Becton Dickinson, Mountain View, CA) and 5-(4,6-dichlorotnazinyl) amınofluoresceinconjugated $\alpha$-CD8 mAb (H35.17.2). Samples were analyzed on a flow microfluorometer (FACS II, Becton Dickinson, Mountain View, CA) gated by a combınation of narrow-angle forward light scatter and perpendicular light scatter to exclude nonviable cells (30).

\section{Lymphocyte cultures}

Spleen cells $\left(4 \times 10^{6} / \mathrm{ml}\right)$ were stimulated in the presence or absence of $1 \times 10^{6} / \mathrm{ml}$ live $L$. major promastigotes, inactivated by $2-5-\mathrm{min}$ irradiation with UV light or L.m.Ag. at $37^{\circ} \mathrm{C}, 7 \%$ $\mathrm{CO}_{2}$ in 24-well Costar plates in a final volume of $2 \mathrm{ml}$. DMEM (Seromed, Berlin, FRG) supplemented with $5 \%$ heat-inactivated FCS (Seromed), L-asparagine (36 mg/), L-glutamine (216 mg/l), L-arginine $(200 \mathrm{mg} / \mathrm{l}), 5 \times 10^{-5} \mathrm{M}$ 2-mercaptoethanol, $10 \mathrm{mM}$ HEPES, $100 \mathrm{U} / \mathrm{ml}$ penicillin and $100 \mu \mathrm{g} / \mathrm{ml}$ streptomycin was used as culture medium. Twenty-four hours later, supernatants (SN) were removed and stored in small aliquots at $-20^{\circ} \mathrm{C}$ until use to measure their content in various lymphokines.

Detection of $1 L-2, I F N-\gamma$, and tumor necrosis factor (TNF) in SN IL-2 activities were determined by measuring the lysosomal enzyme $N$-acetyl- $\beta$-D-hexosaminidase of an IL-2-dependent murıne cytotoxic T cell line (CTLL) as described (31). The CTLL were kindly provided by Dr R. MacDonald, Ludwig Institute for Cancer Research, Epalinges, Switzerland. CTLL ( 4000 cells per well) were incubated with serially diluted ( $\log _{2}$ dilutions) test samples in 96-well flat bottom plates (Costar). Recombinant mouse IL-2 was used as a positive control. Recombinant mouse IL-2 expressed in X63Ag8-653 plasmacytoma cells was a gift from Dr F. Melchers, Basel Institute for Immunology, Basel, Switzerland (32). After $48 \mathrm{~h}$ incubation at $37^{\circ} \mathrm{C}, 7 \% \mathrm{CO}_{2}$ the plates were centrifuged, the supernatants removed, the cells washed twice with PBS, and incubated with $60 \mu$ of substrate. The chromogenic substrate for the hexosaminidase, $p$-nitro-phenyl- $N$-acetyl- $\beta$-Dglucosamınide was dissolved at $7.5 \mathrm{mM}$ in $0.1 \mathrm{M}$ citrate buffer, $\mathrm{pH}$ 5. The substrate solution was mixed with an equal volume of $0.5 \%$ Triton $X-100$ in water and added to the CTLL. After
$16-20 \mathrm{~h}$ incubation at $37^{\circ} \mathrm{C}, 7 \% \mathrm{CO}_{2}$, the color reaction was developed and enzyme activity stopped by addition of $90 \mu$ per

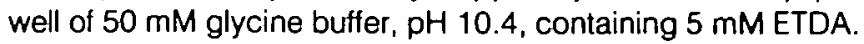
The absorbance was measured at $405 \mathrm{~nm} 10 \mathrm{~min}$ later.

IFN- $\gamma$ activity was measured by ELISA as described (33). ELISA microtiter patates (96-well) (Dynatech, Alexandria, VA) were coated with $5 \mu \mathrm{g} / \mathrm{ml}$ of protein G-purified rat anti-mouse IFN- $\gamma$ mAb R4-6A2, in PBS, $\mathrm{pH}$ 7.2. Free binding sites were blocked with $1 \%(w / v)$ BSA (Fluka, Buchs, Switzerland) for $2 \mathrm{~h}$ at $37^{\circ} \mathrm{C}$. Plates were then washed three times with ELISA washing buffer. Different 2-fold dilutions (in PBS, 1\% BSA) of the test samples were added to the plates, and incubated overnight at $4^{\circ} \mathrm{C}$ in a moist chamber. A standard curve was constructed by assaying serial dilutions of mouse r-IFN- $\gamma$ at starting concentrations of 1600 $\mathrm{U} / \mathrm{ml}$ in PBS, 1\% BSA. After three washes, biotin-labeled protein G-purified rat anti-mouse IFN- $\gamma$ mAb AN-18.17.24 at $1 \mu \mathrm{g} / \mathrm{ml}$ in PBS, 1\% BSA, was added to each well and incubated for $2 \mathrm{~h}$ at $37^{\circ} \mathrm{C}$. After three more washes, wells were incubated for $1 \mathrm{~h}$ at $37^{\circ} \mathrm{C}$ with horseradish peroxidase-conjugated biotin - streptavidin (BRL, Gaithersburg, MD) diluted in PBS. The enzymatic reaction was developed with o-phenylenediamine (BRL) as chromogen ( $1 \mathrm{mg} / \mathrm{ml}$ in $0.1 \mathrm{M}$ sodium citrate buffer, $\mathrm{pH} \mathrm{4.5}$, and $0.012 \% \mathrm{H}_{2} \mathrm{O}_{2}$ ) for $10-15 \mathrm{~min}$ in the dark. The reaction was then stopped by addition of an equal volume of $2 \mathrm{M} \mathrm{H}_{2} \mathrm{SO}_{4}$. Absorbance was measured at $492 \mathrm{~nm}$.

Cells of the fibrosarcoma line WEHI 164, clone 13 (34), a gift of Dr Espevik, University of Trondheim, Trondheim, Norway, were used for the detection of biologically active TNF. Duplicate samples were tested for cytotoxic activity by incubating serial dilutions with $6 \times 10^{5} / \mathrm{ml} \mathrm{WEHI} 164$ clone 13 cells and $0.5 \mathrm{mg} / \mathrm{ml}$ actinomycin D (Sıgma, St Louis, MO) in a final volume of $0.2 \mathrm{ml}$ in flat-bottom microtiter plates. After $24 \mathrm{~h}$ of incubation, 3-(4,5-dimethylthiazol-2-yl)-2,5-diphenyl-tetrazolium bromide (MTT, Sigma) was added (50 $\mu \mathrm{l}$ of MTT solution of $5 \mathrm{mg} / \mathrm{ml}$ in PBS) and incubated for $3 \mathrm{~h}$ at $37^{\circ} \mathrm{C}$ in a moist chamber. Plates were then centrifuged, supernatants removed, and $100 \mu \mathrm{l}$ of 0.04 $\mathrm{N} \mathrm{HCl}$ in isopropanol were added to each well. Plates were agitated for $5 \mathrm{~min}$ to dissolve the blue crystals, and absorbance was measured with a multi-scan ELISA spectrophotometer, using a $550 \mathrm{~nm}$ filter (35). A standard titration of recombinant murine TNF- $\alpha$ ( $r-$ TNF- $\alpha$, kindly provided by Dr G. R. Adolf, ErnstBoehringer-Institute, Vienna, Austria) at dilutions ranging from $653.3 \mathrm{pg} / \mathrm{ml}$ to $0.3 \mathrm{pg} / \mathrm{ml}$ was set up with each assay. Compared to the standard curve, the activity of each sample was expressed in $\mathrm{pg} / \mathrm{ml}$ TNF. The detection threshold of the colorimetric assay for TNF activity was $0.9 \mathrm{pg} / \mathrm{ml}$.

\section{Results}

Effect of administration of $\alpha-C D 4 m A b$ on cutaneous leishmaniasis in $B A L B / c$ mice

The administration of $\alpha-\mathrm{CD} 4 \mathrm{mAb}$ to BALB/c mice has been shown by several investigators to reverse the extreme susceptibility of these mice to infection with $L$. major $(13-15,36)$. Results in Fig. 1 confirm this observation and further demonstrate that this effect does not depend upon the continuous administration of the $\alpha$-CD4 mAb during infection. Mice given $600 \mu \mathrm{g}$ of $\alpha \mathrm{CD} 4$ mAb over a $24-\mathrm{h}$ period at the beginning of infection (10 days before or after infectious challenge) were capable of resolving their lesions around 60 days after infection. Interestingly, the 


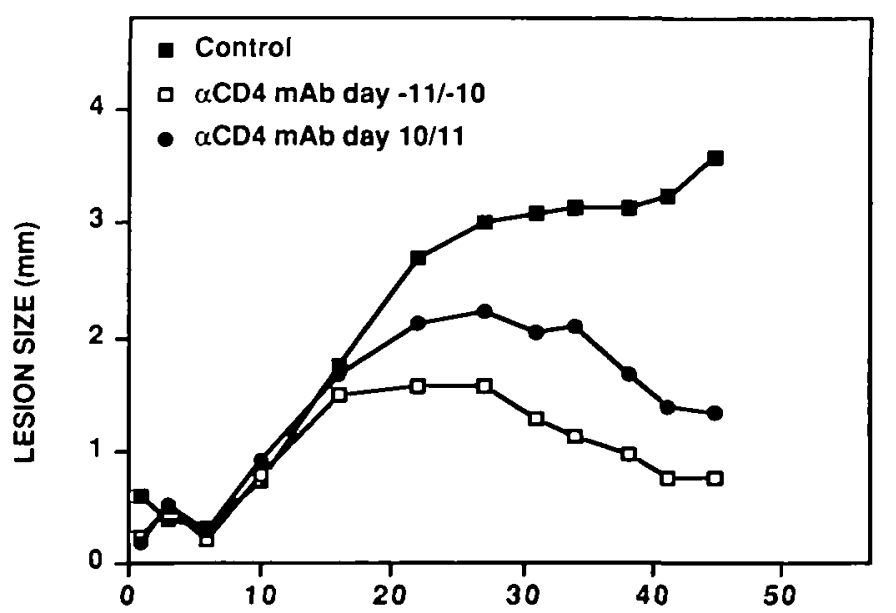

DAYS POST INFECTION

Fig. 1. Lesion development in BALB/c mice after treatment with $\alpha$-CD4 mAb. Groups of susceptible BALB/c mice (10 mice per group) were infected s.c. in one hind footpad with $2 \times 10^{6}$ virulent $L$. major promastigotes. At the indicated times before or after infection, the animals recerved two injections of $300 \mu g \alpha-C D 4$ mAb I.p. Lesion size was determined by subtracting the footpad thickness of the non-infected footpads from the infected ones

administration of $\alpha$-CD4 mAb at later times (20 days after infection) did not result in a beneficial effect on the course of disease (data not shown). Although the administration of mAb resulted in the elimination of more than $95 \%$ of CD4 ${ }^{+} \mathrm{T}$ cells 2 days later, 60 days after infection the percentage and the absolute number of $\mathrm{CD}^{+}{ }^{+} \mathrm{T}$ cells in lymph nodes of cured mice was very similar to that seen in lymphoid tissues of normal BALB/C mice (data not shown). The challenge of BALB/c mice, cured as a result of administration of $600 \mu \mathrm{g} \alpha$-CD4 $\mathrm{mAb}$ at the beginning of a primary infection led to the development of small lesions that resolved spontaneously within 5 weeks, indicating that these mice are immune to reinfection (Fig. 2).

$\mathrm{CD8}^{+} \mathrm{T}$ cells play a role in the control of cutaneous leishmaniasis in $B A L B / C$ mice rendered resistant by the administration $\alpha$-CD4 mAb at the beginning infection

Since previous results from this laboratory have shown that $\mathrm{CD}^{+}+\mathrm{T}$ cells contribute to the resistance to infection in immune mice $(9,10)$ it was of interest to determine whether or not $\mathrm{CD} 8^{+}$ $T$ cells also contribute to the ability of susceptible mice to resolve their primary lesions as a result of administration of $600 \mu \mathrm{g}$ of $\alpha$-CD4 mAb at the beginning of infection. BALB/c mice were infected s.c. in one hind footpad with $2 \times 10^{6}$ stationary phase L. major promastigotes and separated into four groups. One group was left untreated as a control. Mice from the second group received $600 \mu \mathrm{g}$ of $\alpha$-CD4 mAb GK $1.524 \mathrm{~h}$ after infection. Mice from the third group also received $600 \mu \mathrm{g}$ of $\alpha-\mathrm{CD} 4 \mathrm{mAb} 24 \mathrm{~h}$ after infection and weekly injections of $150 \mu \mathrm{g} \alpha$-CD8 mAb H35, initiated 8 days after infection. Mice from the fourth group received only weekly injections of $150 \mu \mathrm{g} \alpha$-CD8 mAb. The disease progression was monitored not only by measuring the size of cutaneous lesions but also by determination of the numbers of viable parasites in the lesions by limiting dilution analysis (19).

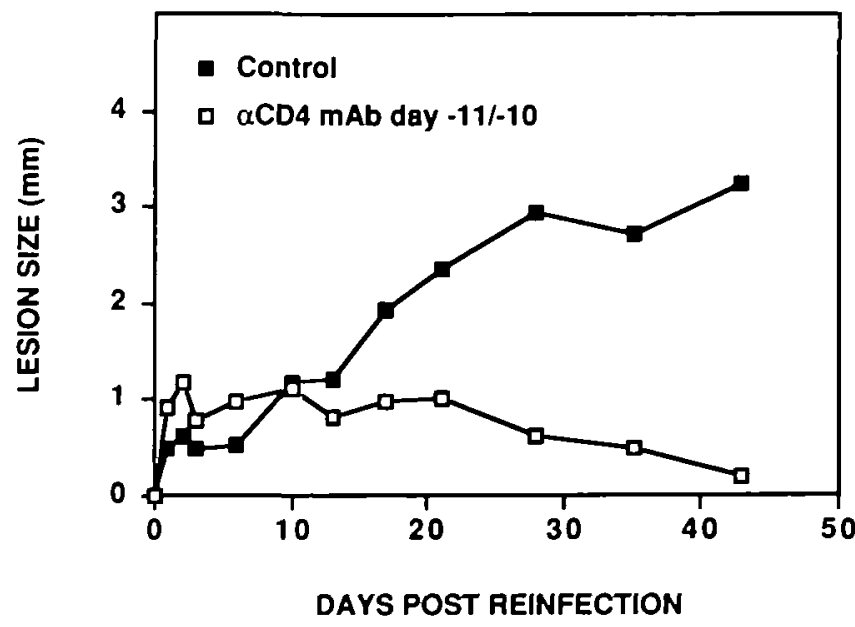

Flg. 2. Course of infection in cured $B A L B / c$ mice. Susceptible BALB/c mice, cured as a result of two injections of $300 \mu \mathrm{g} \alpha-\mathrm{CD} 4 \mathrm{mAb}$ at day -11 and day -10 before infection, were reinfected 60 days later with $2 \times 10^{6}$ virulent $L$. major promastigotes in the footpad opposite to the site of primary infection. The development of lesions was determined by subtracting the footpad thickness of the healed footpads from the reinfected ones. Primary infected BALB/c mice were used as controls $(n=7)$.

Compared to control infected mice, both the time course of lesion development (data not shown) and the parasite numbers in the lesions of mice treated only with $\alpha-C D 8$ mAb once per week were not significantly different (for example, $9.25 \times 10^{7}$ parasites/lesion in control infected mice and $6.7 \times 10^{7}$ parasites/lesion in $\alpha$-CD8 treated BALB/C mice on day 47 after infection). Thus, under the present experimental conditions, a protective effect of $C D 8^{+} T$ cells could not be revealed during the course of a primary infection in susceptible mice.

Results shown in Fig. 3 indicate that mice treated once with $\alpha-\mathrm{CD} 4 \mathrm{mAb}$ at the beginning of infection and also administered $\alpha$-CD8 mAb during the course of infection developed larger lesions than mice treated only with $\alpha$-CD4 mAb at the beginning of infection. Moreover, compared to mice treated only once with $\alpha-\mathrm{CD} 4 \mathrm{mAb}$, the numbers of viable parasites in lesions of mice also given $\alpha$-CD8 mAb were significantly higher as determined on day 88 after infection. It is important to stress that the therapeutic effect of a single injection of $600 \mu \mathrm{g} \alpha-\mathrm{CD} 4 \mathrm{mAb}$ could not be completely reversed by weekly administration of the $\alpha$ CD8 mAb, since the lesions of those mice never reached the size of the lesions of controf infected mice, which lost their footpads around 55 days after infection. The degree of depletion of CD8 $+\mathrm{T}$ cells from lymphoid tissues after the administration of $\alpha \cdot C D 8$ mAb following the regimen described above was documented by FACS analysis. For example, at day 88 the absolute number of $\mathrm{CD}^{+}{ }^{+} \mathrm{T}$ cells in the spleens of mice administered $\alpha$-CD 8 mAb was reduced by $90 \%$ compared to mice receiving only $\alpha-\mathrm{CD} 4 \mathrm{mAb}$ at the beginning of infection. More importantly, when enumerating the viable parasites by the quantitative limiting dilution analysis, the lesions of mice given a single injection of $\alpha-\mathrm{CD} 4 \mathrm{mAb}$ and weekly injections of $\alpha-\mathrm{CD} 8$ $\mathrm{mAb}$ contained about a million times more parasites than the lesions of mice treated with only a single dose of $\alpha-C D 4 \mathrm{mAb}$. These data indicate that resistance to infection, which is seen 


\begin{tabular}{|c|c|c|}
\hline $\begin{array}{l}\text { Treatment of mice } \\
\text { with mAb }\end{array}$ & Parasites/lesion & $\begin{array}{l}\text { LESION SIZE } \\
(\mathrm{mm})\end{array}$ \\
\hline$\alpha \operatorname{CD} 4$ once & 3 & \\
\hline \multirow[t]{2}{*}{$\begin{array}{l}\alpha \text { CD4 once } \\
\alpha C D 8 \text { weekly }\end{array}$} & $4 \times 10^{6}$ & \\
\hline & & 2 \\
\hline
\end{tabular}

Fig. 3. Contribution of $C D 8^{+} T$ cells to the reduction of lesion-size and parasite load in susceptible BALB/c mice, rendered resistant by injection of $\alpha$-CD4 mAb at the beginning of infection. BALB/c mice (4 groups of 6 mice) were infected s.c. in one hind footpad with $2 \times 10^{6}$ vrulent $L$. major promastigotes. One day later, mice from two groups received a single injection of $600 \mu \mathrm{g} \alpha$-CD4 mAb i.p. In one of the groups treated with a single injection of $600 \mu \mathrm{g} \alpha$-CD4 mAb as well as in one control infected group, CD8 ${ }^{+}$T cells were depleted by weekly injections, initiated 8 days after infection, of $150 \mu \mathrm{g} \alpha$-CD8 mAb throughout the entre course of the experiment. Lesion size was determined by subtracting the footpad thickness of the non-infected footpads from the infected ones. Parasite limiting dilution analysis was performed 88 days after infection. The control infected $\mathrm{BALB} / \mathrm{c}$ mice and the infected mice which were treated only with $\alpha$-CD8 mAb once per week lost their footpads around day 55 after infection and therefore the parasite burden in the lesions of these two groups was only determined on day 47 after infection. On that day, the size of lesions in these two groups of mice was $>4 \mathrm{~mm}$.

In susceptible mice treated with $\alpha$-CD4 mAb at the beginning of infection, depends-at least partly-upon the activity of $\mathrm{CD8^{+ }}$ T cells.

Furthermore, the immunity to renfection which is seen in $\mathrm{BALB} / \mathrm{C}$ mice rendered resistant by the injection of $600 \mu \mathrm{g}$ of $\alpha$-CD4 mAb at the beginning of a primary infection was found to depend mainly upon the CD8 $+T$ cell activity expressed early during reinfection. Indeed, a single i.v. injection of $100 \mu \mathrm{g}$ of a $\alpha$-CD8 mAb at the tıme of infectious challenge of cured BALB/C mice led to the development of severe lesions. In contrast, a similar treatment with $\alpha$-CD4 mAb did not hamper the resolution of secondary lesions (Fig. 4).

Contribution of $\mathrm{CD} 8^{+} T$ cells to lymphokine production by spleen cells of $B A L B / C$ mice rendered resistant by a single injection of $\alpha-C D 4 m A b$

It appears that the effect of $T$ cells on the course of cutaneous leishmaniasis depends upon the activity of the lymphokınes they secrete $(16,17,37)$. Therefore, the production of several lymphokines was measured in the supernatants of specificallyactivated spleen cells from mice of the different groups described above, at times when the lesions of $\alpha$-CD4 mAb-treated mice were resolved. Results in Fig. 5 show that compared to control infected mice, the spleen cells from mice cured as a result of treatment with a single dose of $\alpha$-CD4 $\mathrm{mAb}$ at the beginning of infection produced significantly higher amounts of IFN- $\gamma$ in response to stimulation with live promastigotes or L.m.Ag when tested 88 days after infection. This difference in lymphokine production is not due to a different composition of the spleen cells put into culture, since the percentage of $\mathrm{CD} 4^{+}$and $\mathrm{CD} 8^{+}$ $T$ cells in the spleens of cured mice was restored to normal values. The spleens of mice cured by a single injection of $\alpha-C D 4 \mathrm{mAb}$ at the beginning of infection contained $16.5 \% \mathrm{CD}^{+}{ }^{+} \mathrm{T}$ cells and $6.3 \% \mathrm{CD}^{+}+\mathrm{T}$ cells and the spleens of control infected mice contained $11.7 \% \mathrm{CD}^{+}$and $5.7 \% \mathrm{CD}^{+}{ }^{+} \mathrm{T}$ cells. Similar results were observed with IL-2 and TNF. In contrast, lymphokine

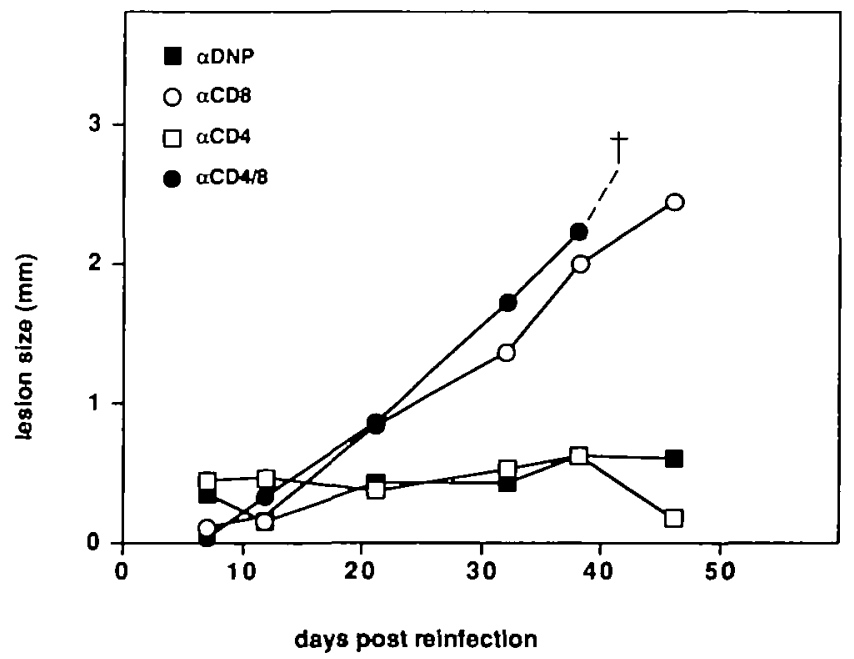

Fig. 4. $\mathrm{CD} 8^{+} \mathrm{T}$ cells contribute to immunity to reinfection in BALB/C mice, rendered resistant by the injection of $600 \mu \mathrm{g} \alpha-\mathrm{CD} 4 \mathrm{mAb}$ at the beginning of infection. BALB/c mice were infected s.c. in one hind footpad with $2 \times 10^{6}$ virulent $L$. major promastigotes. At days 10 and 11 after infection the animals received two injections of $300 \mu g \alpha$-CD4 mAb i.p. After the primary lesions were healed, mice were divided into four groups ( $n$ - 6 mice per group) and injected i.v. with $100 \mu \mathrm{g}$ of either $\alpha$-DNP. $\alpha-\mathrm{CD} 4$ or $\alpha-\mathrm{CD} 8$ or a combination of $\alpha-\mathrm{CD} 4$ and $\alpha-\mathrm{CD} 8 \mathrm{mAb} .6 \mathrm{~h}$ later all mice were reinfected with $2 \times 10^{6}$ virulent $L$. major promastigotes in the footpad opposite to the site of primary infection. The course of reinfection was monitored by measuring the lesion development.

production by spleen cells of mice given $600 \mu \mathrm{g}$ of $\alpha-\mathrm{CD} 4 \mathrm{mAb}$ at the beginning of infection and in addition treated weekly with $\alpha-\mathrm{CD} 8$ mAb was reduced to values below those seen in control infected mice. Compared to mice cured as a result of a single injection of $\alpha$-CD4 mAb at the beginning of infection, the addltional treatment with $\alpha-C D 8$ mAb resulted in a $75 \%$ reduction 
of $\mathrm{CD} 8+\mathrm{T}$ cells and in a $70 \%$ Increase of $\mathrm{CD} 4+\mathrm{T}$ cells in the spleen.

We observed that stımulatıon of immune spleen cells with live promastigotes as a source of antigen resulted in the release of hıgher amounts of lymphokines than stımulation with L.m.Ag. It is noteworthy that, using a very sensitive immuno-assay for the detection of IFN- $\gamma$, it was possible to detect significant amounts of IFN- $\gamma$ in supernatants from spleen cells from infected BALB/C mice upon specific restimulation with live promastigotes in vitro (Fig. 5).

In none of the supernatants taken $24 \mathrm{~h}$ after stimulation of freshly isolated lymphoid cells could measurable amounts of IL-5 or IL-4 be detected.

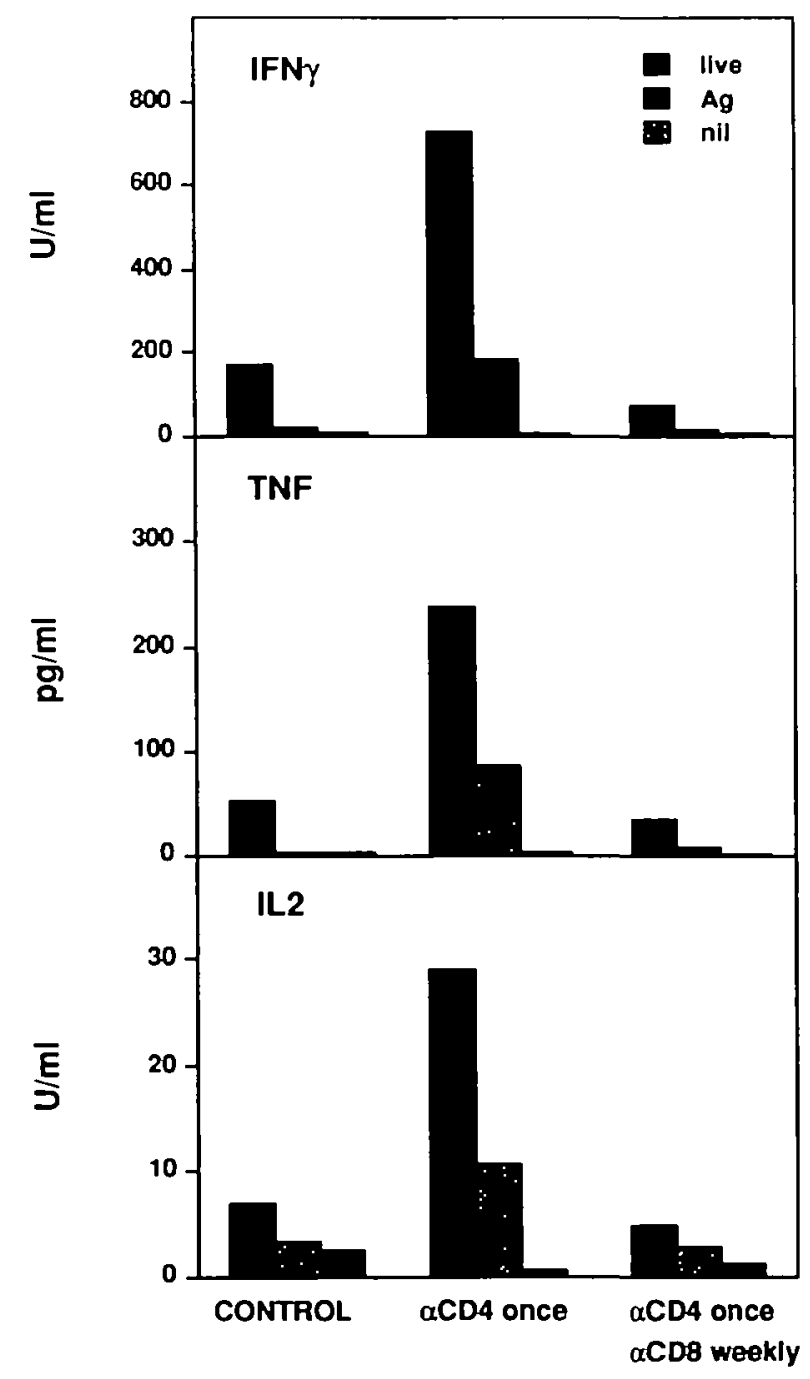

Fig. 5. Contribution of $C D 8^{+} T$ cells to lymphokine production by spleen cells from $B A L B / c$ mice rendered resistant by a single injection of $\alpha-C D 4$ $\mathrm{mAb}$. Spleen cells $\left(4 \times 10^{6} / \mathrm{ml}\right)$ of either control infected BALB/c mice, or BALB/c mice cured as a result of injection of $600 \mu \mathrm{g} \alpha-\mathrm{CD} 4 \mathrm{mAb} 1$ day after infection, or of mice injected 1 day after infection with $600 \mu \mathrm{g}$ $\alpha-C D 4 \mathrm{mAb}$ and depleted of CD8 ${ }^{+} \mathrm{T}$ cells by weekly injections of $150 \mu \mathrm{g}$ $\alpha$-CD8 mAb, were stimulated in vitro with $1 \times 10^{6} / \mathrm{ml}$ live $L$. major promastigotes or $1 \times 10^{6} / \mathrm{ml} \mathrm{L.m.Ag.} \mathrm{on} \mathrm{day} 88$ after infection. $24 \mathrm{~h}$ later, supernatants were removed and tested for IFN- $\gamma, \mathrm{IL}-2$, and TNF.
DTH responses in BALB/C mice rendered resistant by the injection of $\alpha-C D 4 m A b$ at the beginning of infection: analysis of the role of $\mathrm{CD}^{+}$and $\mathrm{CD} 8^{+} T$ cells

The results described above indicate that the $\mathrm{CD}^{+} \mathrm{T}$ cell subset is involved in the state of resistance resulting from one injection of $\alpha$-CD4 mAb in BALB/c mice. Therefore, experiments were devised to detect the actual triggernng of Leishmania-specific $\mathrm{CD8}^{+} \mathrm{T}$ cells directly in vivo by virtue of their ability to initiate a DTH reaction at the site of injection of viable promastigotes. After complete healing of the primary lesions ( 3 months after infectıon), mice were divided into three groups. The first group received an i.v Injection of $100 \mu \mathrm{g} \alpha$-DNP mAb, the second

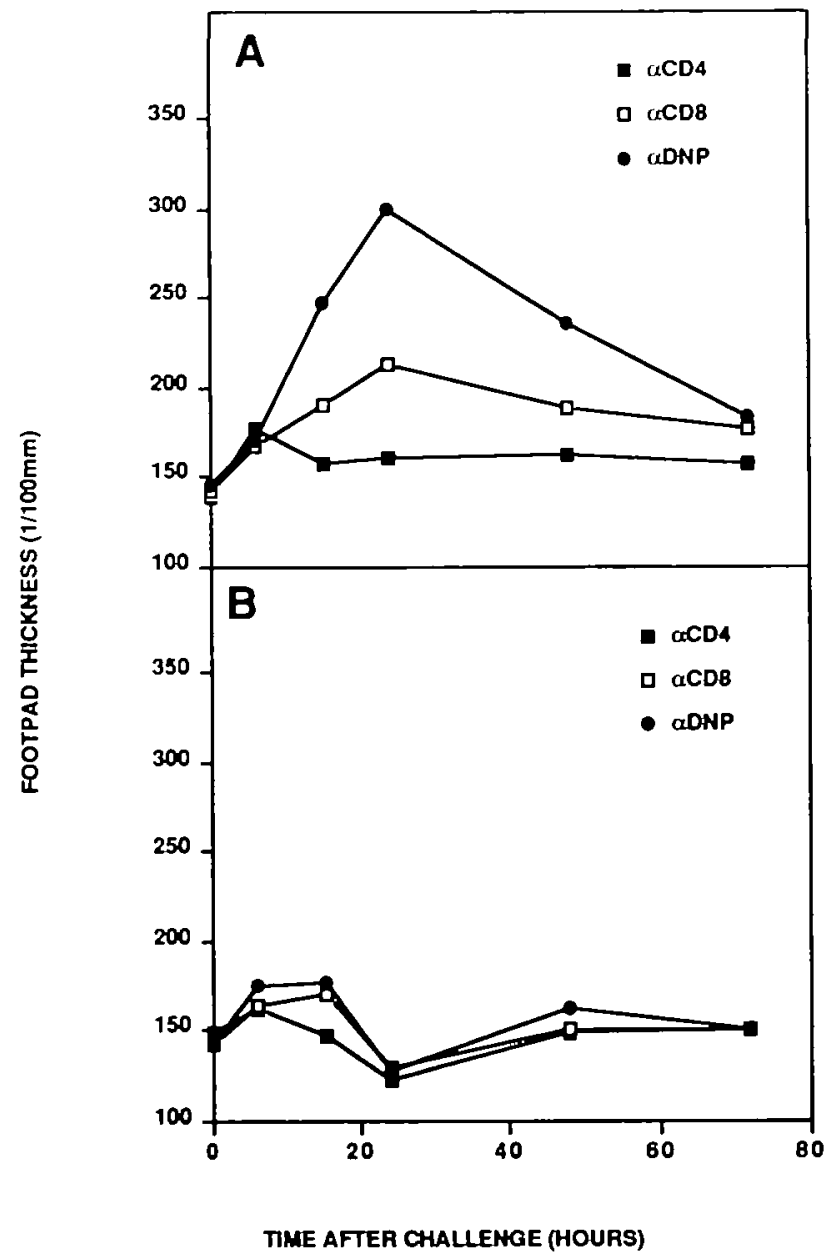

Fig. 6. Analysis of the role of $\mathrm{CD}_{4}{ }^{+}$and $\mathrm{CD} 8^{+} \mathrm{T}$ cell in the development of DTH responses in BALB/C mice, cured as a result of injection of $\alpha$-CD4 mAb at the beginning of infection. BALB/c mice were infected with $2 \times 10^{6}$ virulent $L$. major promastigotes in one hind footpad (A) At days 10 and 11 after infection, mice received two injections of $300 \mu g$ $\alpha$-CD4 mAb i.p. After the primary lesions were healed (3 months after infection), mice were divided into three groups and injected i.v. with $100 \mu \mathrm{g}$ of either $\alpha$-DNP, $\alpha$-CD4 or $\alpha$-CD8 mAb. $6 \mathrm{~h}$ later, mice were challenged with $2 \times 10^{6}$ virulent $L$. major promastigotes in the footpad opposite to the site of primary infection and the DTH response was monitored by measuring the footpad thickness at different times after challenge. (B) Control infected BALB/c mice were treated in the same way as mice of group A, except that they were not injected with $\alpha-C D 4$ mAb at days 10 and 11. 
group received $100 \mu \mathrm{g}$ of $\alpha$-CD4 mAb i.v., and the third group $100 \mu \mathrm{g}$ of $\alpha$-CD8 mAb i.v. After $6 \mathrm{~h}$, all mice were challenged in the footpad opposite to the site of the primary infection with $2 \times 10^{6}$ viable $L$. major promastigotes and the DTH response was assessed by measuring the increase in footpad thickness $6,12,24$, and $48 \mathrm{~h}$ later. Results in Fig. 6 show that in contrast to control infected mice (panel $B$ ), mice cured as a result of Immune intervention with $\alpha$-CD 4 mAb exhibited a strong DTH response (panel A). This delayed inflammatory reaction was

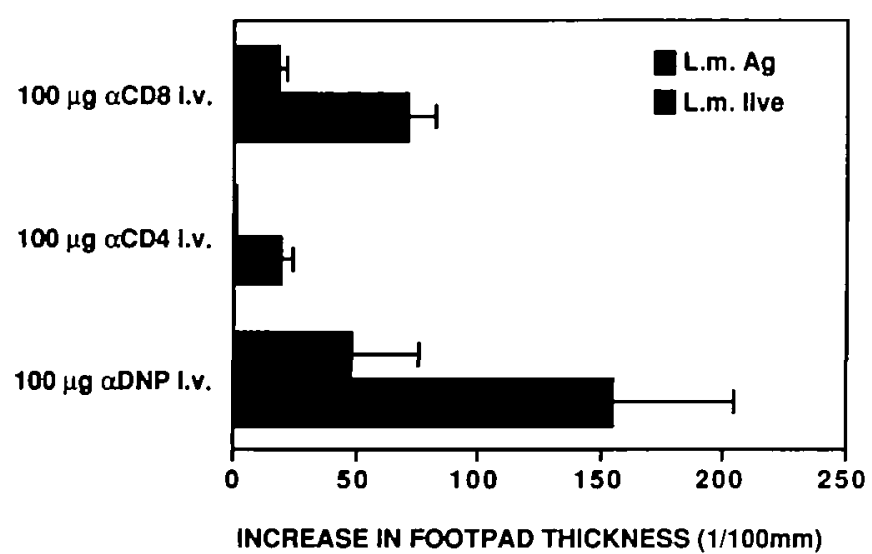

Fig. 7. Elicitation of DTH responses in cured BALB/c mice with viable $L$. major promastigotes or with soluble parasite lysates. After complete healing of the primary lessons ( 3 months after infection), induced by two injections of $300 \mu \mathrm{g} \alpha$-CD4 mAb at days 10 and 11 after s.c. infection with $2 \times 10^{6}$ vrulent $L$. major promastigotes, mice were divided into $S \mid x$ groups and injected i.v. with $100 \mu \mathrm{g}$ of either $\alpha$-DNP, $\alpha$-CD4 or $\alpha$-CD8 mAb. $6 \mathrm{~h}$ later, DTH responses were induced by the injection of either $2 \times 10^{6}$ L.m.AG or $2 \times 10^{6}$ vrulent L. major promastigotes in the footpad opposite to the site of primary infection. The DTH responses were determined by subtracting the size of the footpad before challenge from the footpad thickness after antigenic challenge. abolished in mice given anti-CD4 mAb i.v. $6 \mathrm{~h}$ prior to challenge with viable promastigotes. Although an inflammatory response was still detectable in mice administered anti-CD 8 mAb 6 h before antigenic challenge, the magnitude of the DTH response was significantly reduced. These results clearly indicate that, in addition to $\mathrm{CD}^{+}{ }^{+} \mathrm{T}$ cells, $\mathrm{CD} 8^{+} \mathrm{T}$ cells are also mediators of this DTH response. The finding that deletion of $\mathrm{CD} 4{ }^{+} \mathrm{T}$ cells before challenge with viable parasites abrogates the development of this DTH response strongly suggests that CD4 ${ }^{+} T$ cells are required for $\mathrm{CDB}^{+} \mathrm{T}$ cells to mediate a DTH inflammatory reaction in this experimental system. It is noteworthy that upon challenge with soluble parasite lysates (L.m.Ag), almost no DTH response was elicited in mice from either group (Fig. 7).

Estimation of the number of parasite-specific $\mathrm{CD} 4^{+}$and $\mathrm{CD} 8^{+}$ $T$ cells in lymphoid organs of cured BALB/C mice

The delayed inflammatory reactions (peak at $24 \mathrm{~h}$ ) mentioned above assess the presence of Leishmania-specific $\mathrm{CD} 4^{+}$and $\mathrm{CD}^{+} \mathrm{T}$ cells by their ability to be activated and mobilized to the skın site where viable promastıgotes are injected and to recruit $\mathrm{CR}^{+}$- blood cells (38). This DTH-effector function of both T cell subsets was used as a read-out system to determine the actual number of specific cells in lymphoid tissues. The frequencies of L. major-specific CD4 ${ }^{+}$and CD8 ${ }^{+} \mathrm{T}$ cells, able to transfer locally specific DTH responses, were determined in the dranning lymph nodes, the spleens and the blood of either control infected animals, or BALB/C mice rendered resistant by administration of $\alpha$-CD4 mAb 10 days after infection. Serially diluted cell suspensions, depleted or not of either $\mathrm{CD}^{+}{ }^{+}$or $\mathrm{CD} 8{ }^{+} \mathrm{T}$ cells, were mixed with viable $L$. major promastigotes and injected into the footpads of normal, syngeneic recipients. After $18 \mathrm{~h}$ mice expressing no increase in footpad thickness (DTH-negative transfers) were scored. The numbers of $L$. major-specific $T$ lymphocytes were calculated from the frequency estimation and the numbers of nucleated cells in the lymphoid organs. Results In Fig. 8 confirm and extend previous observations that infec-

Number of $L$. major reactive T lymphocytes

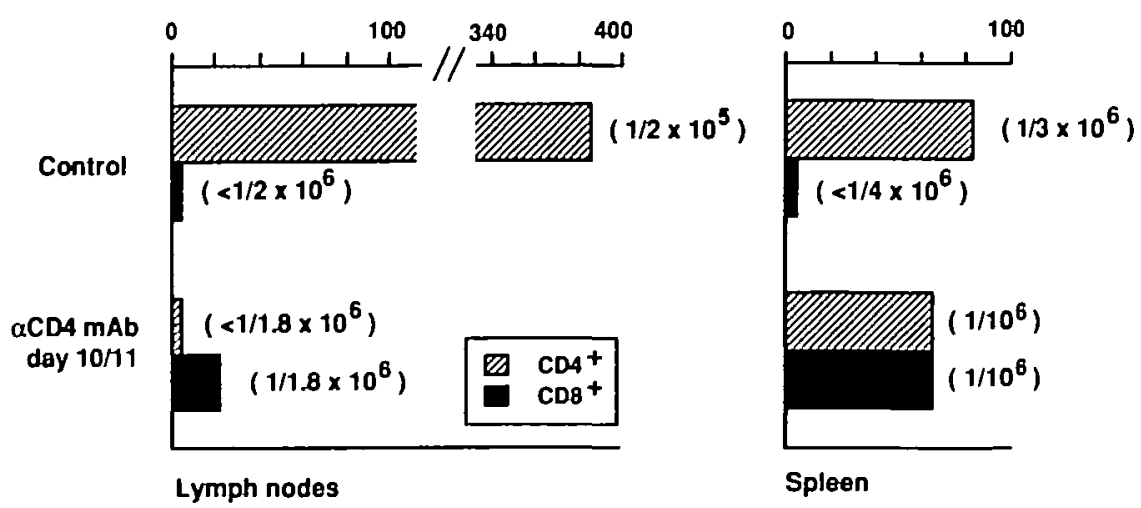

Fig. 8. Number of parasite specific $\mathrm{CD} 4^{+}$and $\mathrm{CD} 8^{+} \mathrm{T}$ cells in spleens and lymph nodes of infected and of cured BALB/c mice. BALB/c mice were infected s.c. in one hind footpad with $2 \times 10^{6}$ virulent $L$. major promastigotes. At days 10 and 11 after infection, one group of BALB/C mice received $300 \mu \mathrm{g} \alpha$-CD4 mAb i.p. After healing of the primary lesion, (day 90 ) spleen and lymph node cell suspensions were prepared from cured and control infected BALB/c mice and depleted of either $\mathrm{CD} 4^{+}$or $\mathrm{CDB}{ }^{+}$T cels by treatment with mAb and complement. Serial dilutions of nucleated cells were transferred along with $2 \times 10^{6}$ viable $L$. major promastigotes into the footpads of navve syngeneic mice (10-12 mice/dilution). $18 \mathrm{~h}$ later, the negative DTH-transfers were scored and the frequency of specific T cells determined. Thereafter, the numbers of $L$. major-specific CD4 ${ }^{+}$and $\mathrm{CDB}^{+} \mathrm{T}$ cells present in lymph nodes and spleens were calculated from the frequency estimation (given in parentheses) and the mumber of nucleated cenls. 


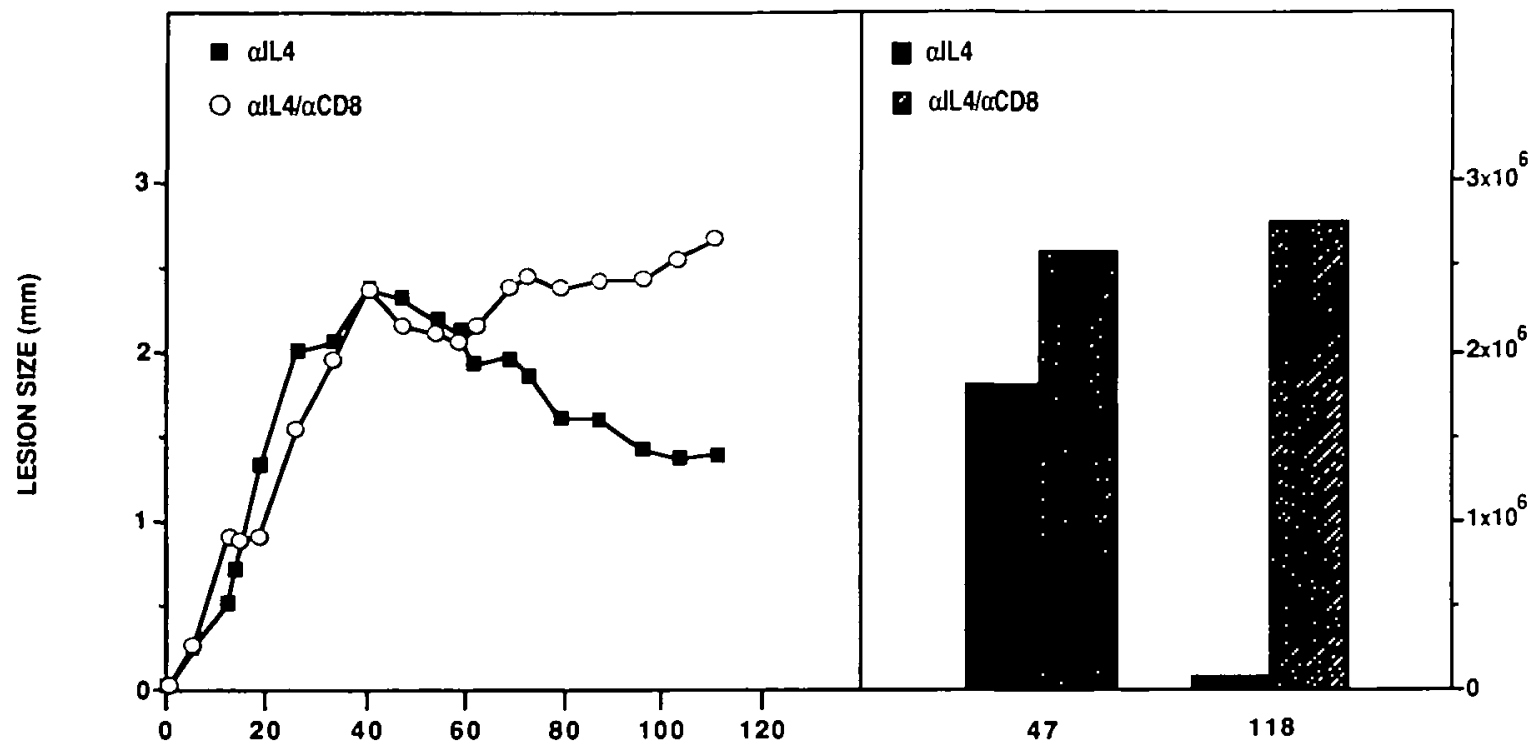

\section{days post Infection}

Flg. 9. Contribution of CD8 ${ }^{+} T$ cells to the reduction of lesion size and parasite burden in susceptible BALB/c mice, rendered resistant by weekly injections of $\alpha \cdot \mathrm{IL} \cdot 4 \mathrm{mAb}$. BALB/c mice were infected S.c. in one hind footpad with $2 \times 10^{6}$ virulent $L$. major promastigotes. One group of mice ( $n=6$ per group) received weekly injections of $500 \mu \mathrm{g} \alpha-\mathrm{IL}-4 \mathrm{mAb}$, starting 2 days before infection. The other group of mice was also treated with $\alpha-1 \mathrm{~L}-4 \mathrm{mAb}$ following the same regimen, and received in addition weekly injections of $150 \mu \mathrm{g} \alpha-\mathrm{CD} 8 \mathrm{mAb}$. Lesion size was determined by subtracting the footpad thickness of the non-infected footpads from the infected ones. The number of viable parasites present in the lesions were determined by limiting dilution analysis at days 47 and 118 after infection.

tion of BALB/C mice leads to the expansion of high numbers of specific CD4 ${ }^{+} \mathrm{T}$ cells capable of mediating DTH in response to viable L. major promastigotes (6). In contrast, compared to controf infected mice, the number of specific CD4 + T cells in draining lymph nodes of cured BALB/c mice was drastically reduced (Fig. 8). An expansion of specififc $C D 8+T$ cells was observed in the spleens of cured BALB/C mice (Fig. 8).

Using this test system, it was possible to detect Leishmaniaspecific $T$ cells in the blood of mice of both groups. In untreated blood of infected control mice, we found that $1 / 3 \times 10^{5}$ nucleated cells was able to transfer specific DTH responses. After treatment of blood cells with $\alpha$-CD4 mAb and complement, the capacity to transfer specific DTH reaction was abrogated. In blood of cured BALB/C mice we found that $1 / 1 \times 10^{5}$ nucleated cells was able to transfer adoptively specific DTH responses. Interestingly, while elimination of $\mathrm{CDB}^{+} \mathrm{T}$ cells abrogated the capacity of nucleated blood cells to transfer Leishmania-specific $\mathrm{DTH}$, the removal of $\mathrm{CD} 4^{+} \mathrm{T}$ cells had no influence on this effect.

The direct demonstration of the DTH-mediating capacity of $\mathrm{CD8}^{+} \mathrm{T}$ cells using this experimental transfer system possibly stems from the fact that these cells were injected into normal recipient mice i.e. with an intact $\mathrm{CD} 4+\mathrm{T}$ cell compartment.

Contribution of $\mathrm{CDB}^{+} T$ cells in the control of cutaneous leishmaniasis in $B A L B / C$ mice rendered resistant by the administration of $\alpha-I L-4 M A b$

Elegant studies by Heinzel ot al. (39) have demonstrated that progression of infection in BALB/c mice is related to the presence of high amounts of IL-4 mRNA in lymphoid organs. In addition, a causal role for IL 4 in susceptibility to infection with $L$. major has been demonstrated by observations showing that the injection of specific IL-4 neutralizing mAb rendered BALB/C mice ressstant to infection (17). The following experiment was performed to determine whether or not $\mathrm{CD8}^{+} \mathrm{T}$ cells contribute to the resolution of lesions in those mice. $B A L B / C$ mice were infected s.c. into one hind footpad with $2 \times 10^{6}$ stationary phase promastigotes. Mice from the first group were left untreated and used as controls. Mice from the second group received weekly injections of $500 \mu \mathrm{g} \alpha-\mathrm{lL}-4 \mathrm{mAb}$, starting 2 days before infection. Mice from the third group were treated with $\mathrm{mAb}$ following the same regimen and in addition, received weekly injections of $150 \mu \mathrm{g} \alpha-\mathrm{CD} 8 \mathrm{mAb}$, also initiated 2 days before infection. Disease progression was evaluated by measuring lesion size and determining the numbers of parasites in lesions. The results in Fig 9 show, in confirmation with published results (17), that BALB/c mice administered $\alpha$-IL-4 mAb are able to control their infection. Interestingly, the combined treatment of $\alpha-\mathrm{IL}-4$ and $\alpha-\mathrm{CD} 8 \mathrm{mAb}$ led to the development of more severe lesions. Determination of parasite numbers at two time points during infection confirm this contention: mice receiving $\alpha-\mathrm{IL}-4$ and $\alpha$-CD8 mAbs harboured $\sim 40$ times more parasites in their lesions than mice treated with $\alpha-I L-4$ mAb only, indicating that the ability to control infection induced in susceptible mice by treatment with $\alpha-I L-4$ $\mathrm{mAb}$ requires the participation of $\mathrm{CD} 8^{+} \mathrm{T}$ cells. The effect of $\mathrm{CD} 8+\mathrm{T}$ cell depletion in mice treated with $\alpha-\mathrm{IL}-4 \mathrm{mAb}$ on the control of infection could only be seen at late tumes during infection. 


\section{Discussion}

The results presented in this paper strongly suggest that parasitespecific $\mathrm{CDB}^{+} \mathrm{T}$ cells contribute to the host's defense against infection with the obligate intracellular parasite $L$. major. The protective effect of $\mathrm{CD8} 8^{+} \mathrm{T}$ cells has been revealed in susceptibje BALB/c mice rendered resistant as a result of two different interventions on the immune system. First, evidence has been presented that $C D 8+T$ cells are important for the control of infection occurring in BALB/c mice as a result of an early treatment with a single dose of $\alpha$-CD4 mAb. Secondly, the establishment of a state of immunity to reinfection developing in those mice was shown to be dependent upon an anti-leishmanial effector function of $\mathrm{CDB}^{+} \mathrm{T}$ cells, since the administration of $100 \mu \mathrm{g} \alpha$-CD8 mAb prior to infectious challenge allowed unrestricted disease progression in these otherwise immune mice (Fig. 4). Thirdly, CD8 $+\mathrm{T}$ cells are also involved in the resolution of lesions and the reduction of parasite burden which occurs in susceptible BALB/c mice treated with $\alpha-I L-4$ mAb. This last observation is supported by results showing that CD8 + lymphoid cells from $\alpha-\mathrm{IL}-4$ treated, cured BALB/C mice have the capacity to transfer adoptively partial protection into 200 R-irradiated syngeneic recipients (17). The beneficial effect of the administration of $\alpha \cdot \mathrm{IL}-4 \mathrm{mAb}$ on the course of cutaneous leishmaniasis in susceptible BALB/c mice is somewhat surprising, since, in our hands, no release of $\mathrm{IL}-4$ was detectable upon specific activation in vitro of freshly isolated spleen and lymph node cells from infected BALB/C mice, using HT2 cells as detection system (I. Müller and J. Louis, unpublıshed observations). However, it is possible that IL-4-producing cells are concentrated at the site of infection, where this lymphokine could be neutralized by specific antibodies.

It has been suggested that $\mathrm{CD}^{+}{ }^{+} \mathrm{T}$ cells need to be permanently elıminated in order for $\mathrm{CD} 8+T$ cells to be activated and to perform a protective function in experimental leishmaniasis (8). The results presented in this paper clearly indicate that the beneficial effect of $\mathrm{CD} 8^{+} \mathrm{T}$ cells on the development of lesions can occur in susceptible mice with a normal number of $\mathrm{CD}^{+}$ $T$ cells in their lymphoid tissues. Indeed, the percentage of $\mathrm{CD}^{+}{ }^{+} \mathrm{T}$ cells in lymphoid organs of $\alpha \cdot \mathrm{IL}-4$ treated mice was normal, and the proportion of $\mathrm{CD}_{4}{ }^{+} \mathrm{T}$ cells in the spleen and lymph node of mice treated with a single dose of $\alpha$-CD4 mAb at the beginning of infection was restored to normal values at the time when the protective role of $C D 8^{+} T$ cells was evident. Furthermore, the weekly treatment of mice with $\alpha$-CD 8 mAb did not adversely affect the numbers of $\mathrm{CD} 4+T$ cells as compared to the controls. Under the two experimental conditions described here, the protective effect of CD ${ }^{+} T$ cells could be detected by measuring the size of the lesion; however, this protective effect was much more striking when the number of viable parasites in the lesions were enumerated (Figs 3 and 9). Thus, the results presented here demonstrate again that, since progression of the lesion size does not necessarily correlate with the number of parasites in the lesions, the precise quantitation of parasite numbers in infected tissues represents the more reliable means to evaluate any protective effect of the immune system on experimental leishmaniasis $(8,40)$.

Using a very sensitive limiting dilution approach (21), which allows the detection of a single, specific $T$ cell that is able to mediate DTH, increased numbers specific $\mathrm{CD} 8+T$ cells were found in lymphoid organs of $B A L B / c$ mice rendered resistant to infection as a result of immunointervention with $\alpha$-CD4 mAb (Fig. 8). The presence of specific CD8 ${ }^{+} T$ cells in the blood of such mice shows moreover that these cells are able to circulate. In order to express their anti-Leishmania effector functions, these specific CD8 ${ }^{+}$T cells must be mobilized from the recirculating pool to the infected site where they are specifically activated. Results obtained suggest that $\mathrm{CD} 4{ }^{+} \mathrm{T}$ cells are required for $\mathrm{CD8}^{+} \mathrm{T}$ cells to fully express their capacity to mediate DTH responses, a conclusion currently being investigated in more detail. It is well documented that the elicitation of DTH responses depend upon the mobilization of circulating sensitized $T$ cells to the site of antigenic challenge and their subsequent ability to recruit $\mathrm{CR}^{+}$blood cells (38). Thus, these results showing that the administration of $\alpha-C D 8$ mAb prior to antigenic challenge with viable $L$. major promastigotes significantly impairs parasitespecific DTH responses strongly suggest that specific CD8 ${ }^{+} \mathrm{T}$ cells are recruited to the site of lesion where they restrict parasite growth.

The expansion of parasite-specific CD8 $+\mathrm{T}$ cells in these mice indicates that parasite antigens are presented in the context of MHC class I molecules. In this respect it is of interest that in all the experiments described in this report, the optimal stimulation of effector functions of CD8 ${ }^{+} \mathrm{T}$ cells (DTH and lymphokine production) was dependent upon the use of living promastigotes as a source of antigen. Thus, it seems that some antigens of this intracellular microorganism, which lives exclusively in the phagosome-lysosome compartment, may, after processing, somehow associate with class I MHC products of their host cells. A hypothetical leak of some parasite products from those vesicles to the cytosol would make parasite antigens available for the $\mathrm{MHC}$ class I pathway of presentation (42). It is also possible that peptides from Leishmania parasites are released from infected cells and are able to bind to MHC class I molecules expressed on the surface of neighboring uninfected cells. However, our observations that $\mathrm{CD} 8^{+} \mathrm{T}$ cells are required for the elimination of parasites in infected tissues suggest that $\mathrm{CDB}^{+} \mathrm{T}$ cells recognize antigens expressed at the surface of parasitized macrophages. It is worth mentioning that in a variety of infections with intracellular microorganisms, such as mycobacteria and Listeria, the development of protective immunity also depends upon the triggering of $\mathrm{CD} 8+\mathrm{T}$ cells, and that vaccination with viable microorganisms confers optimal protection $(41,42)$.

Several mechanisms could account for the protective effect of $\mathrm{CD8}^{+} \mathrm{T}$ cells in experimental cutaneous leishmaniasis. Activation of parasitized macrophages by $T$ cell-derived lymphokines is considered to be the essential mechanism by which parasites are destroyed in infected tissues. Thus, it is possible that the protective function of $\mathrm{CD} 8+\mathrm{T}$ cells is expressed through production of macrophage-activating cytokines. Results in Fig. 5 indicate that the release of IFN- $\gamma$, IL-2 and TNF by specificallyactivated spleen cells from BALB/C mice, cured as a result of treatment with $\alpha-\mathrm{CD} 4 \mathrm{mAb}$ at the initiation of infection, was drastically reduced after depletion of $\mathrm{CD8} 8^{+} \mathrm{T}$ cells in vivo. These results clearly indicate that $\mathrm{CD8}+\mathrm{T}$ cells participate in the production of cytokines which have been ascribed anti-leishmanial effector functions (16,43-45). A direct cytotoxic effect of $\mathrm{CD}^{+} \mathrm{T}$ cells on parasitized macrophages cannot, however, be excluded.

A final point which merits emphasis is the fact that significant amounts of IFN- $\gamma$ were measured in supernatants of specifically- 
activated lymphoid cells from infected, susceptible BALB/c mice (Fig. 5 and manuscript in preparation). Inasmuch as release of IFN- $\gamma$ is significantly higher upon stimulation of lymphoid cells from infected BALB/C mice with living parasites, it would be of interest to determine the phenotype of the T cells from these mice capable of releasing these lymphokines. Thus, our results further indicate that the susceptibility of BALB/c mice to infection with $L$. major cannot simply be ascribed to an inablity to produce IFN- $\gamma$.

\section{Acknowledgements}

We thank Drs R. J. Etges and U. Fruth for critical reading of the manuscript. This work was supported by grants from the Swiss National Science foundation, the UNDPNorld BankWHO Special Programme for Research and Training in Tropical Disease and the Institut Pasteur

\section{Abbreviations}

$\begin{array}{ll}\text { CR 3 } & \text { type } 3 \text { complement receptor } \\ \text { CTLL } & \text { cytotoxic T cell line } \\ \text { DNP } & 2,4 \text {-dintrophenyl } \\ \text { DTH } & \text { delayed-type hypersensitivity } \\ \text { IFN } & \text { interferon } \\ \text { IL } & \text { interleukin } \\ \text { L.m.Ag } & \text { Leishmania major antigen } \\ \text { LNC } & \text { lymph node cells } \\ \text { SN } & \text { supernatant } \\ \text { TNF } & \text { tumor necrosis factor }\end{array}$

\section{References}

1 Behin, R, Mauel, J, and Sordat, B. 1979 Leishmanua tropica: pathogenicity and in vitro macrophage function in strans of inbred mice. Exp. Parasitol. 48:81.

2 Handman, E, Ceredıg, R, and Mitchell, G. F. 1979. Munne cutaneous letshmaniasis disease patterns in intact and nude mice of varıous genotypes and examination of some differences between normal and infected macrophages Aust. J. Exp. Med Sci. 57.9

3 Liew, F. Y. 1986. Cell-mediated Immunity in experimental cutaneous lesshmaniasis. Parasitol. Today 2:264.

4 Liew, F. Y. 1989. Functional heterogeneity of $\mathrm{CD}^{+}{ }^{+} \mathrm{T}$ cells in letshmaniasis. Immunot. Today 10:40.

5 Louls, J. and Milon, G., eds. 1987. Immunobiology of experimental leishmaniasis. 20th Forum in Immunology. Ann. Int. Pasteur/mmund. 138:737.

6 Milon, G, Titus, R. G., Cerottini, J.-C., Marchal, G., and Louis, J. A. 1986. Higher frequency of Leishmania major specific L3T4 + T cells in susceptible BALB/c as compared with resistant CBA mice. J. Immunol. 136:1467.

7 Titus, R. G., Milon, G., Marchal, G., Vassalli, P., Cerottıni, J.C., and Louis, J. A. 1987. Involvement of specific Lyt-2+ T cells in the immunological control of experimentally induced murine cutaneous leishmaniasis. Eur. J. Immunol. 17:1429.

8 Hill, J. O., Awwad, M., and North, R. J. 1989. Elimination of CD4 ${ }^{+}$ suppressor T cells from susceptible BALB/c mice releases $\mathrm{CD8} 8^{+} \mathrm{T}$ lymphocytes to mediate protective immunity against Leishmania. J. Exp. Med. 169:1819.

9 Farrell, J. P., Müller, I., and Louis, J. A. 1989. A role for Lyt2 ${ }^{+}$T cells in resistance to cutaneous leishmaniasis in immunized mice. J. Immunol, 142:2052.

10 Müller, I., Garcia-Sanz, J. A., Titus, R., Behin, R., and Louis, J. 1989. Analysis of the cellular parameters of the immune responses contributing to resistance and susceptibility of mice to infection with the intracellular parasite Leishmania mapor. Immunol. Rev. 112:95.

11 Roberts, M., Kaye, P. M., Milon, G., and Blackwell, J. M. 1989. Studies of immune mechanisms in $\mathrm{H}-11$ linked genetic susceptiblity to murine visceral leishmaniasis. In Hart, D. T., ed., Leishmaniasis. The Current
Status and New Strategies for Control, p. 259. NATO ASI Series, 163. Plenum Press, New York.

12 Stern, J. J., Oca, M. J., Rubin, B. Y., Anderson, S. L, and Murray, H. W. 1988. Rote of L3T4 ${ }^{+}$and Lyt2 ${ }^{+}$cells in experimental visceral leishmaniasis. J. Immunot. 140:3971.

13 Titus, R. G., Ceredig, R., Cerottini, J.-C, and Louls, J A. 1985. Therapeutic effect of anti-L3T4 monoclonal antubody GK 1.5 on cutaneous leishmanasis in genetically susceptible BALB/c mice. J. Immunol. 135:2108.

14 Liew, F. Y., Millott, S., Letchuk, R., Cobbold, S., and Waldmann, H. 1989. Effect of CD4 monoclonal antibody in vivo on lesion development, delayed-type hypersensitivity and interleukn 3 production in experimental murine cutaneous leishmaniasis. Clin. Exp. Immunol. 75:438.

15 Sadick, M. D., Heinzel, F. P., Shigekane, V. M., Fisher, W. L., and Locksiey, R. M. 1987. Cellular and humoral immunity to Leishmania major in genetically susceptble mice after in vivo depletion of L3T4 ${ }^{+}$ T cells. J. Immunal. 139:1303.

16 Müller, I., Pedrazzini, T., Farrell, J. P., and Lours, J A. 1989. T cell responses and immunity to experımental infection with Leishmania major. Annu. Rev. Immunol. 7:561.

17 Sadick, M. D, Heinzel, F. P., Holaday, B. J., Pu, R. T., Dawkins, R. S., and Lockstey, R. M. 1990 . Cure of murine lesshmaniasis with antiInterleukin-4 monoclonal antıbody. Evidence for a T cell dependent, IFN- $\gamma$ independent mechanism. J. Exp. Med. 171'115.

18 Louls, J A, Moedder, E., Behin, R., and Engers, H. D. 1979. Recognition of protozoan parasite antigens by murine T lymphocytes 1 Induction of specric $T$ lymphocyte dependent prolferative response to Leishmania tropica. Eur. J Immunol. 9:841.

19 Titus, A. G., Marchand, M , Boon, T., and Louis, J. A. 1985. A limiting dilution assay for quantifying Leishmania major in tussue of infected mice. Parasite Immunol. 7.545

20 Marchal, G., Seman, M., Milon, G, Truffa-Bachi, P., and Zilverfarb, V. 1982. Local transfer of skin delayed type hypersenstivity initiated by a single T lymphocyte J. Immunot. 129.954

21 Marchal, G., and Milon, G 1984. Numeration of DTH-mediating T lymphocytes in mice under optimal turation conditions. Ann. Immunol. (Inst. Pasteur) 135C.353.

22 Dialynas, D. P., Quan, Z. S., Wall, K. A., Pierres, A., Quintas, J., Loken, M. R, Pierres, M., and Fitch, F. W. 1983. Characterization of the murine $T$ cell surface molecule, designated L3T4, identified by monoctonal antbody GK 1.5. Similarity of L3T4 to the human Leu3/T4 molecule. J. Immunot. 131.2445.

23 Sarmiento, M., Glasebrook, A. L., and Fitch, F W. 1980. IgG or IgM monoclonal antibodies reactive with different determinants on the molecular complex beaning Lyt2 antigen block $T$ cell mediated cytolysis in the absence of complement. J. Immunol. 125:2665.

24 Pierres, M., Goridis, C., and Golstein, P. 1982. Inhibition of murine $T$ cell mediated cytolysis and $T$ cell prolferation by a rat monoclonal antibody immunoprecipitating two lymphoid cell surface polypeptides of 94,000 and 180,000 molecular weight. Eur. J. Immunot., 12.60 .

25 Ohara, J. and Paul, W. E 1985. Production of a monoctonal antibody to and molecular characterization of B-cell stimulatory factor 1. Nature (London) 315:333.

26 Prat, M., Gribaudo, G. Comoglio, P. M. Cavallo, G., and Landolfo, S. 1984. Monoclonal antibodies aganst murine gamma interteron. Proc. Natl Acad. Sci USA 81.4515.

27 Sprtalny, G. L. and Havell, E A. 1984. Monoctonal antibody to murine gamma interferon inhibits lymphokine induced antiviral and macrophage tumoricidal activities. J. Exp Med. 1591560.

28 Ceredig, R., Lowenthal, J. W. Nabholz, M., and MacDonald, H. R. 1985. Expression of interleukin 2 receptors as a differentiation marker on intrathymic stem cells. Nature 314:98.

29 Chassoux, D. M., Linarez-Cruz, L. G., Bazin, H., and Stanislawski, $M .1988$. K-celtmediated cytotoxicity induced with rat monoclonal antibodies. I. Antibodies of various isofypes differ in their ability to induce cytotoxicity mediated by rat and human effectors. Immunotogy 65:623.

30 MacDonald, H. R., Lees, R. L., Sordat, B., Zaech, P., Maryansku, J. L., and Bron, C. 1981. Age-associated increase in expression of the $T$ cell surface markers Thy $1, L y t-1$, and $L y t-2$ in congenitally athymı (nu/nu) mice: analysis by flow cytometry. J. Immunal. 126.865.

31 Landegren, U. 1984. Measurement of cell numbers by means of the 
endogenous enzyme hexoseaminidase. Applications to detection of lymphokines and cell surface antigens. J. Immunol. Methods 67:379.

32 Karasuyama, H. and Metchers, F. 1988. Establishment of mouse cell lines which constitutively secrete large quantities of interleukin 2,3 , 4 or 5 using modified cDNA expression vectors. Eur. J. Immunot. 18:97.

33 Stade, S. S. and Langhorne, J. 1989. Production of interferon gamma during infection of mice with Plasmodium chabaudi Immunobiol. 179.353

34 Espevik, T. and Nissen-Meyer, J 1986. A highly sensitive cell Ine, WEHI 164 clone 13, for measuring cytotoxic factor/tumor necrosis factor from human monocytes. J. Immunol. Methods 95:99.

35 Mosmann, T. 1983. Rapid colorimetnc assay for cellular growth and survival Application to proliferation and cytotoxicity assays. J. Immunot. Methods 65:55

36 Müller, I. Pedrazuni, T., and Louis, J. A 1988. Experimentally induced cutaneous Lesshmaniasis: are $\mathrm{L}_{3} \mathrm{~T}_{4}{ }^{+} \mathrm{T}$ cells that promote paraste growth distinct from those mediating resistance? Immunol. Lett. 19:251.

37 Belosevic, M., Finbloom, D. S., van der Meide, P. H., Slayter, M. V., and Nacy, C. A 1989. Administration of monoclonal anti-IFN-y antibodies in vivo abrogates natural resistance of $\mathrm{C} 3 \mathrm{H} / \mathrm{HeN}$ mice to infection with Lesshmania major. J Immunal 143:266.

38 Rosen, H., Milon, G., and Gordon, S. 1989. Antubody to the murine type 3 complement receptor inhibits T tymphocyte-dependent recruitment of myetomonocytic cells in vivo. J. Exp. Med. 169:535

39 Heinzel, F. P., Sadick, M. D., Holaday, B. J., Coffman, R. L., and Locksley, R. M. 1989. Reciprocal expression of interferon $\gamma$ or interleukin 4 during the resolution or progression of murine leishmaniasis Evdence for expansion of distinct helper $T$ cell subset. J. Exp. Med. 169:59.

40 Hill, J. O. North, R. J., and Collins, F. M. 1983. Advantages of measuring changes in the number of viable parasites in murine models of expenmental cutaneous leishmaniasis. Infect. Immun. 39:1087.

41 Kaufmann, S. H. E. 1988. CD8 ${ }^{+}$T lymphocytes in intracellular microbial infection. Immund. Today 9.168.

42 Brunt, L M., Portnoy, D. A., and Unanue, E. A 1990 . Presentation of Listena monocytogenes to $\mathrm{CD} 8^{+} \mathrm{T}$ cells requires secretion of hemolysin and intracellular bacterial growth J. Immunol. 145:3540.

43 Titus, R. G., Sherry, B., and Cerami, A. 1989 Tumor necrosis factor plays a protective role in expenmental murine cutaneous lesshmanıasis. J. Exp. Med. 170.2097.

44 Liew, F. Y., Parkinson, C , Millot, S., Severn, A., and Carrier, M. 1990. Tumor necrosis factor (TNF $\alpha$ ) in leishmaniasis. I. TNF $\alpha$ mediates host protection against cutaneous lesshmanasis. Immunotogy 69:570.

45 Belosevic, M., Finbloom, D S., Meltzer, M. S., and Nacy, C A. 1990. IL-2 a cofactor for induction of activated macrophage resistance to infection $J$ Immund. 145:831. 
